\author{
Artur Dariusz Kubacki \\ Katowice/Sosnowiec
}

\title{
WYBRANE PROBLEMY PRZEKEADU NIEMIECKICH I POLSKICH DOKUMENTÓW Z ZAKRESU PRAWA SPADKOWEGO
}

\footnotetext{
Zarys treści: Artykuł jest przyczynkiem o charakterze praktycznym, w którym na przykładzie dokumentów spadkowych występujących w międzynarodowym obrocie prawnym podjęta zostaje próba udowodnienia, iż w celu zachowania ekwiwalencji funkcjonalnej, tj. utworzenia w języku docelowym najbardziej naturalnych ekwiwalentów dla jednostek tekstu w języku wyjściowym, przekładu tego typu tekstów nie można ograniczać jedynie do tłumaczenia wyrazów lub terminów w oparciu o źródła słownikowe i dostępne leksykony. Poszukiwanie ekwiwalentów funkcjonalnych musi opierać się na wielopłaszczyznowej analizie lingwistycznej tekstów paralelnych, która pozwala zastosować w przekładzie uzualne środki i sposoby utekstowienia charakterystyczne dla określonego tekstu specjalistycznego.
}

$\mathrm{T}^{\mathrm{s}}$ eoretycy przekładu prawniczego najwięcej uwagi poświęcają sposobom ustalania ekwiwalencji terminów prawnych. W tłumaczeniu specjalistycznym w zakresie terminologii, frazeologii i stylistyki obowiązuje konwencja docelowego języka prawa ${ }^{1}$. Bez wykorzystania i szczegółowej analizy tekstów paralelnych tłumacz nie byłby w stanie zachować odpowiedniego rejestru i uzusu terminologicznego typowego dla określonej rzeczywistości prawnej języka docelowego. Na przykładzie pism z zakresu prawa spadkowego występujących w obrocie prawnym z krajami niemieckojęzycznymi wskażemy na

${ }^{1}$ Język prawa to dla celów niniejszej pracy rejestr nadrzędny wobec wyróżnionych przez Wróbla dwóch odmian stylowych, tj. języka prawnego (języka aktów normatywnych) i języka prawniczego (języka, który występuje w praktyce społecznej związanej z prawem). 
podobieństwa i różnice terminologiczno-frazeologiczne, a tym samym na pułapki, jakie czyhają na tłumacza, który opiera się jedynie na źródłach słownikowych.

\section{Spadkowe procedury prawne w prawie polskim i niemieckim}

Do zadań sądów cywilnych (wydziały ds. nieprocesowych) należy m.in. rozstrzyganie wszystkich roszczeń finansowych i zobowiązań między osobami fizycznymi, w tym spraw własnościowych i spadkowych. Aby można było nabyć spadek, osoba tym zainteresowana musi złożyć wniosek w wydziale cywilnym sądu rejonowego właściwego ze względu na ostatnie miejsce zamieszkania spadkodawcy. Wnioskodawca podaje w nim obligatoryjnie krąg spadkobierców. Sąd przeprowadza postępowanie i wydaje odpowiednie postanowienie. Uczestnikami postępowania zostają spadkobiercy ustawowi i testamentowi. Sąd z urzędu bada, kto jest spadkobiercą i czy został sporządzony testament. Przy dziedziczeniu testamentowym sąd otwiera i ogłasza testament. Na wniosek spadkobiercy, tj. nabywcy części spadku albo udziału, sąd może wszcząć postępowanie o dział spadku. We wniosku należy określić majątek będący przedmiotem działu spadku. Roszczenia spadkowe o tzw. zachowek mogą także zgłaszać spadkobiercy ustawowi pominięci w testamencie, którzy nie zostali wydziedziczeni przez spadkodawcę. Zachowek nie przysługuje wszystkim spadkobiercom ustawowym, ale tylko zstępnym, małżonkowi oraz rodzicom. Sprawy z zakresu prawa spadkowego uregulowane są w art. 922-1088 czwartej księgi polskiego k.c. oraz w art. 1922-2385 piątej księgi niemieckiego k.c.

\section{Dokumenty obowiązujące w międzynarodowym obrocie prawnym}

Po przystąpieniu Polski do Unii Europejskiej zawiązała się ścisła współpraca pomiędzy sądami cywilnymi. Kraje UE związane są pięcioma rozporządzeniami Rady UE z 2000 i 2001 r. dotyczącymi międzynarodowego postępowania cywilnego. Ponadto Polska podpisała następujące regulacje prawne z krajami niemieckojęzycznymi:

1. Austria - umowa o wzajemnych stosunkach w sprawach $\mathrm{z}$ zakresu prawa cywilnego oraz o dokumentach (DzU $1974 \mathrm{Nr} 6,33,34$ i 35),

2. Niemcy - układ między Rządem RP a Rządem RFN o dalszym ułatwianiu obrotu prawnego na podstawie konwencji haskiej z dnia 1 marca 1954 r. dotyczącej procedury cywilnej (DzU 1994 Nr 30, poz. 110 i 111). 
Dla ułatwienia kontaktów pracowników polskiego i niemieckiego wymiaru sprawiedliwości ustawodawca przygotował wzory pism dotyczące obrotu prawnego w sprawach cywilnych w stosunkach z RFN wraz ze słowniczkiem pojęć prawnych i objaśnieniami (por. Ciszewski 2004: 91).

Ponadto do prawidłowego przetłumaczenia dokumentów spadkowych nieodzowne będą takie pomoce, jak niemiecki kodeks cywilny Bürgerliches Gesetzbuch (BGB), austriacki kodeks cywilny Allgemeines Bürgerliches Gesetzbuch (ABGB) oraz oryginalne dokumenty polskie, niemieckie i austriackie z zakresu prawa spadkowego.

Bez lingwistycznej analizy ww. pozycji tłumacz nie jest w stanie dokonać poprawnego tłumaczenia dokumentów spadkowych, a dostępne na rynku słowniki mono- i bilingwalne niestety nie dają mu oczekiwanej pomocy w poszukiwaniu poprawnej leksyki specjalistycznej.

\section{Podobieństwa i różnice frazeologiczno-terminologiczne}

Sądy powszechne zlecają tłumaczom przysięgłym sporządzenie tłumaczenia poświadczonego typowych dokumentów występujących w obrocie prawnym w sprawach spadkowych. Są to: wezwanie na posiedzenie sądu, wniosek o stwierdzenie nabycia spadku lub wniosek o dział spadku i zniesienie współwłasności oraz testament sporządzony notarialnie lub testament holograficzny (sporządzony pismem odręcznym, opatrzony datą i podpisany przez spadkodawcę). Przekład wymienionych tu dokumentów nastręcza wiele trudności ze względu na duże różnice występujące w motywach nazwotwórczych, których tłumacz, nie posiadając wykształcenia prawniczego, nie jest w stanie poprawnie ustalić. Do prawidłowego przekładu owych dokumentów, tj. wytworzenia tekstu ze zwyczajowymi wyrażeniami prawniczymi, niezbędna jest bowiem analiza dokumentów i aktów niemieckich (por. Iluk, Kubacki 2006: 6).

Jeżeli istnieją podobieństwa terminologiczne lub frazeologiczne między nazwami w polskiej i niemieckiej kulturze prawnej, proces translacyjny przebiega szybko i sprawnie. Tłumacz - bez konieczności przeprowadzania szczegółowej analizy składników nazwy - przyporządkowuje odpowiedniki w drugim języku, wykorzystując słowniki bilingwalne o charakterze specjalistycznym. Oto przykładowe wyrażenia i zwroty prawnicze, które zawierają podobne struktury nazwotwórcze wynikające z przystawalności systemów prawnych obydwu państw: 
Tabela 1

\begin{tabular}{|r|l|l|}
\hline 1. & spadkobierca & Erbe (m) \\
\hline 2. & spadkodawca & Erblasser \\
\hline 3. & wnioskodawca & Antragsteller \\
\hline 4. & uprawniony do spadku & Erbberechtigter \\
\hline 5. & pełnomocnik do doręczeń & Zustellungsbevollmächtigter \\
\hline 6. & uczestnik postępowania & Verfahrensbeteiligter \\
\hline 7. & kurator spadku & Nachlasspfleger \\
\hline 8. & przedsiębiorca bez osobowości prawnej & $\begin{array}{l}\text { Unternehmer ohne Rechtspersönlich- } \\
\text { keit }\end{array}$ \\
\hline 9. & wezwanie & Ladung \\
\hline 10. & stawiennictwo & Erscheinen \\
\hline 11. & sygnatura akt & $\begin{array}{l}\text { Aktenzeichen (D) / Geschäftszeichen } \\
\text { (A) }\end{array}$ \\
\hline 12. & zasiedzenie & Ersitzung \\
\hline 13. & spadek & $\begin{array}{l}\text { Erbe (n), Erbschaft, Nachlass (D) } \\
\text { Verlassenschaft (A, CH) }\end{array}$ \\
\hline 14. & dziedziczenie ustawowe & gesetzliche Erbfolge \\
\hline 15. & dziedziczenie testamentowe & testamentarische Erbfolge \\
\hline 16. & otwarcie spadku & Nachlasseröffnung \\
\hline 17. & właściwość sądu & Zuständigkeit des Gerichts \\
\hline 18. & zniesienie współwłasności & Aufhebung des Miteigentums \\
\hline 19. & pozostawić testament & ein Testament hinterlassen \\
\hline 20. & wpisać do księgi wieczystej & ins Grundbuch eintragen \\
\hline 21. & doręczyć postanowienie & einen Beschluss zustellen \\
\hline 22. & wyznaczyć termin posiedzenia sądu & $\begin{array}{l}\text { den Termin der Gerichtssitzung anbe- } \\
\text { raumen }\end{array}$ \\
\hline
\end{tabular}


Na podstawie przykładów z tabeli można wysunąć kilka istotnych wniosków dających się zaobserwować na przykładzie tłumaczenia dokumentów z zakresu prawa spadkowego:

1) Nazwy osób występujących w pismach spadkowych (przykłady 1-8) wykazują podobne motywy nominacyjne, które w niemczyźnie wyrażane są najczęściej za pomocą rzeczowników złożonych (Erbberechtigter, Verfahrensbeteiligter), natomiast w polszczyźnie za pomocą złożeń (spadkobierca, wnioskodawca) oraz skupień terminologicznych (przedsiębiorca bez osobowości prawnej). Oba procesy słowotwórcze mają na celu lepsze odzwierciedlenie treści pojęcia i jeszcze bardziej precyzyjne określenie jego miejsca w systemie terminologicznym rejestru prawniczego (por. Iluk 1992a: 70).

2) Proces translacyjny ułatwia znacznie podobna struktura formalna polskich i niemieckich terminów występujących w pismach spadkowych (przykłady 9-22). Generalnie można stwierdzić, że dominują w nich sufiksy derywacyjne (wezwanie $=$ Ladung, zasiedzenie $=$ Ersitzung) oraz skupienia terminologiczne o charakterze rodzajowo-gatunkowym typu rzeczownik + przymiotnik (dziedziczenie ustawowe = gesetzliche Erbfolge), przy czym kolejność składników w nazwie niemieckiej jest odwrotna. Ponadto w konfrontowanych językach występują nazwy dwuskładnikowe w postaci skupień o charakterze nierodzajowo-gatunkowym o tej samej strukturze formalnej typu rzeczownik + rzeczownik w dopełniaczu (właściwość sądu = Zuständigkeit des Gerichts) lub o powyższej strukturze formalnej w polszczyźnie $\mathrm{z}$ odpowiednikiem niemieckim w postaci złożenia dwuskładnikowego (otwarcie spadku = Nachlasseröffnung),

3) W przypadku kilku terminów wybór leksemu jest ograniczony uzusem językowym typowym dla określonego kraju niemieckojęzycznego. Problem ten można doskonale zilustrować na przykładzie dwóch rzeczowników polskich, tj. spadek i sygnatura akt. W zależności od otoczenia kontekstowego spadek określa się w RFN jako Erbschaft, Erbe (n), Nachlass (szczególnie w złożeniach jako człon określający, np. Nachlassgericht, Nachlasssache, $\mathrm{Na-}$ chlasspfleger, Nachlassrichter, Nachlassverbindlichkeiten), natomiast Austria i niemieckojęzyczna Szwajcaria preferują termin Verlassenschaft. Podobnie ma się rzecz z terminem sygnatura akt, który w kulturze prawnej Austrii ma formę Geschäftszeichen, a w Niemczech określany jest jako Aktenzeichen, przy czym należy podkreślić, iż - dążąc do kompensacji - urzędnicy używają tego terminu najczęściej w postaci skróconej, tj. odpowiednio GZ i AZ. Zadaniem tłumacza jest sporządzenie tłumaczenia zorientowanego funkcjonalnie na konkretną odmianę języka źródłowego.

4) Na podstawie analizy syntagm nominalno-werbalnych występujących w dokumentach spadkowych można stwierdzić, że istnieje wiele konstrukcji 
morfologiczno-semantycznych, które praktycznie nie wykazują żadnych różnic strukturalnych ani nazwotwórczych.

Wśród skupień terminologicznych pochodzących z korpusu o zakreślonej powyżej tematyce można znaleźć kilka takich, które stanowią dla tłumacza prawdziwe wyzwanie. Użyta w języku docelowym struktura jest częściowo lub całkowicie odmienna pod względem motywacji nominacyjnej, natomiast różnica strukturalna jest nieznaczna lub konstrukcja wręcz odpowiada formie składniowej w języku wyjściowym. Potwierdzają to następujące przykłady:

\section{Tabela 2}

\begin{tabular}{|c|c|c|}
\hline 1. & Wniosek o stwierdzenie nabycia spadku & $\begin{array}{l}\text { Antrag auf Erteilung des Erbscheins } \\
\text { Erbscheinsantrag }\end{array}$ \\
\hline 2. & Wniosek o dziat spadku & $\begin{array}{l}\text { Antrag auf Nachlassauseinandersetzung } \\
\text { Antrag auf Nachlassaufteilung }\end{array}$ \\
\hline 3. & $\begin{array}{l}\text { Wniosek o udzielenie pomocy praw- } \\
\text { nej przez odebranie zapewnienia spad- } \\
\text { kowego }\end{array}$ & $\begin{array}{l}\text { Antrag auf Rechtshilfeleistung durch } \\
\text { Entgegennahme der erbrechtlichen } \mathrm{Zu} \text { - } \\
\text { sage }\end{array}$ \\
\hline 4. & $\begin{array}{l}\text { Wniosek o stwierdzenie nabycia praw } \\
\text { do spółdzielczego mieszkania lokator- } \\
\text { skiego (nie własnościowego) }\end{array}$ & $\begin{array}{l}\text { Antrag auf Feststellung des Erwerbs von } \\
\text { Rechten auf eine Genossenschafts-Miet- } \\
\text { wohnung (keine Eigentumswohnung) }\end{array}$ \\
\hline 5. & Oświadczenie o przyjęciu spadku & $\begin{array}{l}\text { Erklärung über die Annahme der Erb- } \\
\text { schaft } \\
\text { Erbannahmeerklärung }(\mathrm{D}, \mathrm{CH}) \\
\text { Erbantrittserklärung }(\mathrm{A})\end{array}$ \\
\hline 6. & $\begin{array}{l}\text { Postanowienie o stwierdzeniu nabycia } \\
\text { spadku }\end{array}$ & $\begin{array}{l}\text { Beschluss über die Erteilung des Erb- } \\
\text { scheins (D) } \\
\text { Einantwortungsbeschluss (A) }\end{array}$ \\
\hline 7. & $\begin{array}{l}\text { Uzasadnienie } \\
\text { (postanowienia sądowego) }\end{array}$ & $\begin{array}{l}\text { Entscheidungsgründe (D) } \\
\text { Begründung (A) }\end{array}$ \\
\hline 8. & Rzecznik patentowy & Patentanwalt \\
\hline 9. & Gospodarstwo rolne & Landwirtschaftsbetrieb \\
\hline 10. & $\begin{array}{l}\text { Wniosek o .................................. jest zatem } \\
\text { zasadny }\end{array}$ & $\begin{array}{l}\text { Der Antrag auf ............................. ist daher } \\
\text { geboten }\end{array}$ \\
\hline
\end{tabular}




\section{Cd. tabeli 2}

\begin{tabular}{|r|l|l|}
\hline 11. & Kodeks cywilny (PL) & Zivilgesetzbuch (PL) \\
\hline 12. & Kodeks cywilny (D) & Bürgerliches Gesetzbuch (D) \\
\hline 13. & Kodeks cywilny (A) & $\begin{array}{l}\text { Allgemeines Bürgerliches Gesetzbuch } \\
(\mathrm{A})\end{array}$ \\
\hline 14 & Kodeks postępowania cywilnego (PL) & Zivilverfahrensgesetzbuch (PL) \\
\hline 15. & Kodeks postępowania cywilnego (D) & Zivilprozessordnung (D) \\
\hline
\end{tabular}

$\mathrm{Z}$ analizy lingwistycznej pierwszej grupy przykładów (1-6) wynika, iż przekład grup nominalnych jest utrudniony odmiennymi członami nazwotwórczymi. Z powodu braku propozycji słownikowych tłumaczowi nie pozostaje nic innego, jak sięgnięcie do dokumentów źródłowych, np. niemieckiego kodeksu cywilnego. W RFN i Austrii sąd spadkowy wydaje spadkobiercy zaświadczenie o jego prawach do spadku. Stąd też w niemieckim prawie spadkowym sędziowie - wydając postanowienie sądowe - używają terminu Erteilung des Erbscheins (dosł. wydanie zaświadczenia spadkowego). W Polsce procedura otrzymania spadku jest podobna. Sędzia w drodze postępowania nieprocesowego wydaje postanowienie o stwierdzeniu nabycia spadku. W tłumaczeniu polskiego k.p.c. dokonanym przez Kamilę Miszczuk, które ukazało się w Wydawnictwie C.H. Beck w 2005 r., znajdujemy w $\$ 669$ następujący odpowiednik dla tego terminu: Beschluss über die Festlegung des Antritts der Erbschaft. Na jego podstawie można stwierdzić, że autor tłumaczenia jest zwolennikiem przekładu zorientowanego na język źródłowy. Ja natomiast należę zdecydowanie do zwolenników tłumaczenia zorientowanego na język i kulturę kraju docelowego i dlatego do tłumaczenia wykorzystuję termin mający wieloletnią tradycję $\mathrm{w}$ niemieckim/austriackim prawie cywilnym, który jest tożsamy z rzeczywistością polskiego systemu prawnego, tj. Beschluss über die Erteilung des Erbscheins (D)/Einantwortungsbeschluss (A).

Kolejne przykłady świadczą o trudności w znalezieniu odpowiedniego motywu nominacyjnego w języku niemieckim zarówno w obrębie grup wyrazowych, pojedynczych leksemów, jak i konstrukcji składniowych, np. dziat spadku - Nachlassauseinandersetzung (dosł. rozliczenie spadku), mieszkanie lokatorskie - Mietwohnung (dosł. mieszkanie najemne), gospodarstwo rolne Landwirtschaftsbetrieb (dosł. przedsiębiorstwo rolnicze), rzecznik patentowy Patentanwalt (dosł. adwokat patentowy), wniosek jest zasadny - der Antrag ist geboten (dosł. wniosek jest nakazany). Wybór motywu jest o tyle utrudniony, 
że tłumacz, nie będąc prawnikiem, nie zna praktyki i zasad funkcjonowania określonych instytucji prawnych $\mathrm{w}$ ramach systemu prawnego obowiązującego w danym kraju. W przytoczonych nazwach nie można stosować metody kalkowania, ponieważ przynajmniej jeden ze składników terminu jest formalnie i/lub semantycznie inny (por. Iluk 1992b: 60). Tłumacz zdany jest zatem na poszukiwanie właściwych określeń w aktach prawnych lub w równoległych dokumentach źródłowych poświęconych tej konkretnej gałęzi prawa.

Podczas przekładu dokumentów spadkowych pojawiają się na dodatek różnice w proponowanych ekwiwalentach dla nazewnictwa aktów prawnych, jak to widać w przykładach 11-15. Część tłumaczy stoi na stanowisku, aby przejmować nazwy aktów prawnych z języka docelowego, część natomiast opowiada się za tworzeniem nowych odpowiedników w celu ich eksplicytnego rozróżnienia (por. tłumaczenia aktów prawnych w Wydawnictwie C.H. Beck). W mojej opinii można stosować oba rozwiązania z jednym zastrzeżeniem: w przypadku przejęcia nazwy dokumentu stosowanej w kraju języka docelowego, np. Zivilprozessordnung, należy uzupełnić ekwiwalent - w celu uniknięcia nieporozumień - o przymiotnik wskazujący kraj źródłowy, np. polnische Zivilprozessordnung. Przy okazji warto wspomnieć o kolejności podawania daty i przedmiotu aktu normatywnego w polskiej i niemieckiej tradycji prawnej. W języku polskim najpierw podajemy datę, a potem przedmiot ustawy, $\mathrm{w}$ języku niemieckim natomiast na odwrót, np. Ustawa z dnia 29 września 1994 r. o rachunkowości $=$ Gesetz über die Rechnungslegung vom 29. September 1994.

Na koniec chciałbym poruszyć jeszcze jeden aspekt dotyczący nie tylko tłumaczenia dokumentów z zakresu prawa spadkowego, ale wszystkich pism sądowych. Wielu trudności w ich tłumaczeniu przysparzają nazwy polskich instytucji wymiaru sprawiedliwości. O ile w Niemczech istnieją w tym zakresie zalecenia odgórne w postaci listy urzędowych ekwiwalentów nazw sądów niemieckich (por. Amtliche Bezeichnungen deutscher Gerichte) dla 12 języków (w tym ekwiwalenty polskie), o tyle w Polsce tłumacz - w odniesieniu do języka niemieckiego $^{2}-$ może liczyć jedynie na niejednolite propozycje zawarte $\mathrm{w}$ dostępnych na rynku słownikach specjalistycznych Skibickiego, Kilian, Pieńkosa czy Banaszka. Jak już na wstępie podano, spadkami zajmują się w Polsce sądy rejonowe, a konkretnie wydziały cywilne ds. nieprocesowych. Proponowane ekwiwalenty słownikowe dla sądu rejonowego zawarte są w poniższej tabeli.

2 Źródłem informacji terminologicznej w odniesieniu do języka angielskiego dla nazewnictwa wymiaru sprawiedliwości w Polsce jest książka Administration of Justice in Poland autorstwa M. Jankowskiego i A. Siemaszko (1999), a także przewodnik po wymiarze sprawiedliwości dostępny na stronie internetowej Ministerstwa Sprawiedliwości (www.ms.gov.pl/przewodnik/przew01.pdf). 
Tabela 3

SAD REJONOWY

\begin{tabular}{|l|l|l|l|}
\hline \multicolumn{1}{|c|}{ Banaszek } & \multicolumn{1}{|c|}{ Kilian } & \multicolumn{1}{c|}{ Pieńkos } & \multicolumn{1}{c|}{ Skibicki } \\
\hline $\begin{array}{l}\text { Amtsgericht } \\
\text { Rayonsgericht }\end{array}$ & Amtsgericht & $\begin{array}{l}\text { Amtsgericht } \\
\text { Distriktgericht } \\
\text { Rayonsgericht }\end{array}$ & $\begin{array}{l}\text { Bezirksgericht } \\
\text { Amtsgericht }\end{array}$ \\
\hline
\end{tabular}

Na liście urzędowych ekwiwalentów tłumaczeń niemieckich sądów dla Amtsgericht proponuje się sq̨d grodzki, co wprowadza dodatkowe zamieszanie terminologiczne. Uwzględniając jeszcze odmianę austriacką języka niemieckiego, która rozciąga się także na rejestr prawniczy, tłumacz stoi na rozdrożu w kwestii terminologii, gdyż sąd rejonowy w Austrii określa się mianem Bezirksgericht (por. Krzysztoforska-Weisswasser 1998: 75), a w Polsce tego złożenia używa się obecnie na określenie sądu okręgowego, czyli sądu powszechnego orzekającego w pierwszej i/lub drugiej instancji, powstałego w $1999 \mathrm{r}$. w wyniku reformy ustroju sądów powszechnych z dawnego sądu wojewódzkiego (Woiwodschaftsgericht). W zalecanym przez sądy okręgowe wewnętrznym słowniku branżowym dla określenia sądu rejonowego używa się jednak niemieckiego złożenia Amtsgericht, które podawane jest przez większość polskich i niemieckich autorów słowników dwujęzycznych. Pozostała część nazwy sądu, tj. wydział cywilny ds. nieprocesowych, wykazuje podobną strukturę nominacyjną w języku niemieckim i tłumaczona jest zazwyczaj jako Zivilkammer für nichtstreitiges Verfahren. Na marginesie należy wspomnieć, iż przy nazwie sądu podaje się zarówno w polszczyźnie, jak i niemczyźnie miasto, w którym ma on siedzibę. Polska tradycja nazewnicza przewiduje użycie przyimka „w”, niemiecka natomiast takiego przyimka nie uwzględnia, np. Sąd Rejonowy w Katowicach = Amtsgericht Katowice. Stąd wielu, nawet doświadczonych tłumaczy, popełnia błąd, kalkując całą strukturę nazwy sądu z jednego języka na drugi.

\section{Wnioski}

Tłumaczenia pism spadkowych z języka polskiego na język niemiecki i odwrotnie nie można dokonać tylko w oparciu o ogólną znajomość języka niemieckiego. Konieczne jest zapoznanie się z terminologią specjalistyczną i paralelnymi aktami prawnymi. Wprawdzie wiele skupień terminologicznych, a nawet całych syntagm, można przełożyć, posługując się uniwersalnymi 
słownikami, jednak istotna część z nich przy tego typu przekładzie ulegnie znaczącemu zniekształceniu. Stanie się tak wszędzie tam, gdzie pojawią się różne motywy nazwotwórcze lub wystąpi odmienny sposób ujęcia językowego analogicznej procedury prawnej. Tłumacz musi zatem posiłkować się nie tylko słownikami specjalistycznymi, lecz przede wszystkim aktami prawnymi o równorzędnym statusie. Ponadto im większa będzie jego wiedza o systemie prawnym w kraju ojczystym i krajach języka docelowego, tym bardziej prawdopodobne stanie się znalezienie poprawnego ekwiwalentu.

\section{Literatura}

Amtliche Bezeichnungen deutscher Gerichte, www.auswaertiges-amt.de/diplo/de/Infoservice/Terminologie/Gerichtsbezeichnungen.pdf (dostęp 12.05.2007).

Ciszewski, J., 2004, Obrót prawny z zagranica w sprawach cywilnych $i$ karnych, Warszawa.

Iluk, J., 1992a, „Kontrastive Analyse juristischer Personenbezeichnungen unter wortbildungsmäßigem Aspekt", [w:] Wissenschaftliche Arbeiten zur Literatur und Linguistik, Iluk, J. (red.), Katowice, s. 63-74.

Iluk, J., 1992b, „Voraussetzungen für eine angemessene Übersetzung von Namen öffentlicher Einrichtungen", [w:] Wissenschaftliche Arbeiten zur Literatur und Linguistik, Iluk, J. (red.), Katowice, s. 52-62.

Iluk, J., Kubacki, A. D., 2006, Wybór polskich i niemieckich dokumentów do ćwiczeń translacyjnych, Warszawa.

Jankowski, M., Siemaszko, A., 1999, Administration of Justice in Poland, Warszawa.

Krzysztoforska-Weisswasser, Z., 1998, Polski słownik terminów i pojęć prawniczych, Wiedeń.

Miszczuk, K., 2005, Kodeks postępowania cywilnego. Polnisches Zivilverfahrensgesetzbuch, Warszawa.

\section{Selected problems of translation of German and Polish documents concerning the law of succession}

(summary)

The article is a practical contribution in which, on the basis of inheritance documents used in international legal transactions, an attempt is made to prove that in order to 
achieve functional equivalence, that is in order to find in the target language the most natural equivalents for text units from the source language, the translation of such texts cannot be limited to translating words or terms only with the use of dictionaries and lexicons. Searching for functional equivalents has to be based on a multifaceted linguistic analysis of parallel texts, which makes it possible to use customary means and ways of text formation characteristic of a given specialist text in the process of translation. 